\title{
Efektivitas Otak Anak Usia Dini dalam Mengenal Calistung
}

\author{
Zulfatun Anisah \\ STAI Al Hikmah Tuban \\ Email: Zulfa7664@gmail.com
}

\begin{abstract}
The introduction of calistung in AUD focuses on brain optimization of children. The child's brain has a trillion brain cells and trillions of brain-nerve cell connections. Brain nerves. influenced by the number of myelin that awakened at the age of 0-2 years which will determine the ability of abstract thinking, scientific thinking at the formal stage of operations. The backbone and cerebral cortex are the central nervous system for humans. the physical body of the child can be trained through mild exercise. Other parts of the brain in the form of cerebral cortex handle the functions of intellectual and language. Parents or nannies can provide stimulation as needed. The results suggest that children from families with high language intake received higher IQ scores at age three. So is the case with children who get more cognitive stimulation, they are more skilled in language activities. Age of AUD precisely began to learn to read if it has reached the mental age, ie 5-5.5 years.
\end{abstract}

Keywords: calistung, child brain, myelin, and mental age 


\section{PENDAHULUAN}

Otak merupakan organ tubuh vital manusia yang berfungsi sebagai pusat kontrol dan kendali atas semua sistem dalam tubuh. Bahkan otak dijadikan sebagai acuan mengidentifikasi mutu berpikir seseorang. Anak yang otaknya cerdas sering disebut "otak encer", sedangkan anak yang memiliki keterlambatan berpikir biasa disebut "otak udang". Kedua istilah itu sebagai bentuk representasi daya pikir manusia. Setiap orang tua menginginkan anaknya berotak cerdas. Untuk itu perlu dipersiapkan sejak dini, pembelajaran yang tepat sesuai usia anak. Selain itu, urutan materi stimulasi juga harus sistematis sesuai urutan perkembangan otak anak. Ketepatan pemberian stimulasi diharapkan dapat membentuk syarafsyaraf otak anak berfungsi secara maksimal.

Batita maupun balita disebut sebagai the golden age. Pada usia emas tidak jarang orang tua yang disibukkan untuk mendesak anak ataupun guru untuk mengajarkan calistung kepada AUD. Orang tua menuntut supaya anaknya mahir membaca, menulis, dan berhitung mulai sejak dini. Hal ini bertolak belakang dengan aturan yang diberlakukan oleh Dinas Pendidikan. Aturan yang tertuang dalam surat edaran dari Dirjen Dikdasmen Nomor:1839/C.C2/TU/2009 berisikan tentang kriteria calon peserta didik di MI/SD berusia sekurangkurangnya 6 tahun (Wahyuti, 2010). Adapun bagi siswa yang berusia kurang dari 6 tahun, dilakukan atas dasar rekomendasi tertulis dari pihak yang berkompeten, seperti konselor dan psikolog. Baik yang berusia 6 tahun ataupun kurang dari itu, keduanya tidak diperkenankan untuk menerima tes dalam bentuk apapun.

Faktanya tidaklah demikian. Sekolah tingkat TK/RA/yang sederajat telah memberlakukan pengajaran calistung. Penguasaan calistung bagi AUD dijadikan sebagai patokan bagi sekolah-sekolah $\mathrm{SD} / \mathrm{Ml}$ favorit, sehingga banyak orang tua yang mengejar tuntutan tersebut. Bagi yang lulus TK/RA/sederajat telah menguasai calistung, mereka berkesempatan masuk di sekolah favorit. Hal ini tentu melenceng dari aturan Dikdasmen. Orang tua perlu mengetahui perkembangan sekaligus kemampuan Otak AUD. Dengan begitu, para orang tua dapat mengetahui batasanbatasan knowledge yang tepat dikenalkan dan diajarkan kepada AUD. Waktu yang digunakan untuk mengajarkan membaca, menulis, atau berhitung akan lebih tepat disampaikan. Orang tua perlu mengetahui kapasitas otak anak 
dalam menerima pengajaran calistung. Strategi mengajarkan calistung juga harus tepat. Sistematika atau urutan pengajaran juga perlu diperhatikan oleh orang tua. Dalam artikel ini akan dibahas komposisi otak anak yang berkaitan dengan kesiapan anak dalam mengenal calistung, strategi mengajarakan calistung pada AUD, stimulasi otak pada AUD, serta urutan materi calistung yang tepat diajarkan kepada anak.

\section{DISKUSI}

\section{Perkembangan Otak Anak Usia Dini}

Otak merupakan pusat berpikir, berperilaku, dan bertindak oleh manusia. Otak menjadi bagian yang sangat fundamental dalam memahami sesuatu maupun menerima pengetahuan baru. Selain itu, otak juga menjadi cerminan emosi seseorang, kebudayaan, kejiwaan, bahasa, serta ingatan seseorang. Analoginya, otak sebagai pusat kesadaran orang, sedangkan badan manusia sebagai kudanya (Semiawan, 1997:50). Dengan kata lain, otak adalah mesinnya, sementara tubuh adalah kendaraannya. Kemudi kendaraan bergantung kualitas mesin. Semakin bagus kualitas dan perawatan mesin, maka semakin bagus pula kemudi kendaraannya.

Perkembangan otak manusia supaya optimal dalam menjalankan fungsinya, perlu distimulasi dengan baik sejak dini. Seperti yang dikemukakan oleh Tanner dan Santrock (2007:43) menyatakan bahwa jumlah dan ukuran saraf otak terus bertambah setidaknya sampai usia remaja. Beberapa penambahan ukuran otak, salah satunya disebabkan oleh myelination. Sebuah proses yang banyak melibatkan sel otak dan sistem syaraf yang diselimuti oleh lapisan-lapisan sel lemak yang bersekat-sekat. Setiap rangsangan yang diberikan pada anak, akan membuat myelin pada otak pusat anak berpikir. Pembangunan myelin ini diharapkan terjadi pada seluruh sel otak berpikir anak, meliputi otak besar dan serebrum. Semakin banyak myelin yang terbagun pada usia 0 2 tahun, itu akan menentukan kemampuan abstract thinking, scientific thinking pada tahap formal operasional.

Seluruh sistem saraf manusia termasuk anak terdiri atas dua bagian utama: (a) tulang punggung yang terdiri dari sederetan tulang punggung yang bersambung-sambungan (spinal cord) dan (b) otak. Otak itu sendiri terdiri atas dua bagian: (i) batang otak (brain stem) dan (ii) korteks serebral (cerebral cortex). Tulang punggung dan korteks serebral ini merupakan sistem 
syaraf sentral untuk manusia. Segala ihwal yang dilakukan manusia, baik yang berupa kegiatan fisik maupun mental, semua dikendalikan oleh sistem syaraf ini (Dardjowidjojo, 2012:203).

Batang otak itu sendiri terdiri atas bagian-bagian yang dinamakan medulla, pons, otak tengah, dan cerebellum. Bagian-bagian ini sangat berkaitan dengan fungsi fisikal tubuh, termasuk pernafasan, detak jantung, gerakan, refleks, pencernaan, dan pemunculan emosi (Steinberg, dkk., 2001:312). Melalui fungsi fisikal tubuh itu orang tua atau pengasuh anak dapat mengajarkan anak olah raga ringan. Hal lain yang dapat dilakukan misalnya membiarkan anak bermain lari-lari kecil, lompat, mengayun, naik-turun tangga dan lain sebagainya. Gerakan-gerakan yang dilakukan anak dapat melancarkan peredaran darah dan menyehatkan jantung. Dengan begitu bagian-bagian yang berada di batang otak dapat berfungsi secara optimal.

Adapun bagian otak lainnya yang berupa korteks serebral menangani fungsi-fungsi intelektual dan bahasa. Korteks serebral manusia terdiri atas dua bagian: hemisfir kanan dan hemisfir kiri. Kedua hemisfir ini dihubungkan oleh sekitar 200 juta fiber yang dinamakan korpus kalosum (corpus callosum) (Dingwall, 1998:75). Hemisfir kiri bertugas mengendalikan semua anggota badan bagian kanan, termasuk muka bagian kanan. Sebaliknya, hemisfir kanan mengontrol anggota badan bagian kiri. Hemisfir kiri memegang peran dalam kaitannya dengan bahasa(Geschwind, 1981:113). Terdapat empat daerah besar yang berada dalam hemisfir kiri yang biasa disebut lobe. Empat lobe tersebut diantaranya lobe frontal (frontal lobe), lobe temporal (temporal lobe), lobe osipital (occipital lobe), dan lobe pariental (pariental lobe). Empat lobe ini masing-masing memiliki fungsi yang berbeda. Adanya uraian mengenai pembagian syaraf dalam otak beserta tugasnya. Orang tua atau pengasuh anak dapat memberikan stimulasi sesuai kebutuhan. Lobe frontal bertugas mengurus ihwal yang berkaitan dengan kognisi. Orang tua atau pengasuh dapat mengajak anak ke tempat-tempat yang tidak berbahaya. Ketika diajak pergi ke taman misalnya, anak dapat diperkenalkan dengan aneka tumbuhan, bunga, hewan, serta benda-benda yang ada di sekitar taman. Sekalipun si anak belum mampu berbicara dengan lancar, stimulasi harus kontinyu diberikan, karena alam bawah atau lagu yang ramah 
lingkungan. Selain itu anak juga dapat diajak berbicara sesering mungkin.

Hasil penelitian yang dilakukan oleh psikolog anak dari University of Kansas, Todd Risley dan Betty Hart menyebutkan bahwa anak-anak dari keluarga dengan asupan bahasa yang tinggi (rata-rata 2.153 kata per jam), artinya orang tua bercakap-cakap dengan anak lebih panjang, memperoleh nilai IQ lebih tinggi pada usia tiga tahun dibandingkan dengan keluarga dengan asupan bahasa yang rendah (rata-rata 616 kata per jam), misalnya lebih banyak melontarkan komentar sekilas seperti "jangan" atau "turun" tanpa penjelasan lebih lanjut kepada anak. Penelitian lain yang cukup mencengangkan adalah bahwa bayi sudah mulai belajar aturan tata bahasa sejak awal. Biasanya kita menganut pandangan bahwa anak pertama kali belajar tentang bunyi, lalu memahami kata, baru gabungan beberapa kata. Tapi ternyata tidak demikian yang ditemukan Judit Gervain, ahli saraf kognitif dari Universite Paris Descartes yang melakukan penelitian pada bayi yang baru lahir. Gervain mengatakan bahwa hampir semua bunyi, kata, dan pola bahasa, sudah mulai berkembang bersamaan sejak awal.

Lobe osipital menangani urusan penglihatan. Benda-benda yang ditemui anak dimanapun berada dapat diperkenalkan. Stimulasi hendaknya diberikan secara terus-menerus. Rangsangan yang terus-menerus diberikan oleh orang tua/pengasuh kepada anak dalam bentuk aneka kegiatan, itu akan memperkuat hubungan antar sel-sel otak. Satu sel otak mampu membuat 15.000 hubungan dengan hubungan sel yang lain. pengalaman yang diterima anak akan menentukan bentuk jaringan di dalam otak. Sejak bayi jaringan terbentuk dengan cepat. Masuk usia 3 tahun, otak anak akan membuat 1.000 triliun hubungan. Jumlah tersebut menjadi dua kali lipat dari jumlah hubungan jaringan otak pada orang dewasa. Hubungan otak yang densitas/kerapatannya sangat tinggi akan bertahan sampai usia 10 tahun (Hasan, 2013:46).

Setelah masuk di usia 11 tahun, hubungan antar sel-sel otak tersebut akan diseleksi secara alami. Hubungan sel yang sering digunakan akan semakin kuat dan permanen, sedangkan hubungan sel yang tidak pernah digunakan akan putus/terbuang. Disarankan pada orang tua/pengasuh dapat mengoptimalkan masa-masa emas anak guna memperkuat hubungan jaringan sel pada otak. Lobe pariental mengurusi rasa somaestetik atau rasa yang ada pada tangan, kaki, muka, 
dan sebagainya. Panca indera anak dapat dikenalkan ke benda-benda yang konkret. Benda apapun yang dipegang anak, disentuh, atau yang menempel pada badan anak akan menjadi objek pengetahuan bagi mereka. Tangan dapat menyentuh benda halus seperti boneka atau menyentuh benda kasar seperti karpet. Kaki dapat menginjak lantai halus atau jalan berkerikil. Muka dapat bersentuhan dengan air dingin, dan air hangat. Semakin banyak objek yang diperkenalkan, semakin luas pula kosakata pengetahuan mereka.

Lobe temporal mengurusi hal-hal yang berkaitan dengan pendengaran. Si anak dapat diperdengarkan lagu-lagu edukatif, suara-suara hewan, dan musik. Musik klasik layak diperdengarkan pada anak batita, karena sangat baik untuk memicu perkembangan sel-sel otaknya. Otot-otot telinga bisa diasah kapanpun. Saat duduk di tengah keluarga, di mobil, di bus, atau ketikaa berjalan di luar rumah. Misalnya, ketika berada berada diluar rumah mendengar bunyi bel motor, katakan padanya kalau itu bunyi klakson yang berfungsi memberikan isyarat pada pengguna jalan yang lain.

\section{Komposisi Otak Anak Usia Dini}

Otak anak dengan otak orang dewasa berbeda takarannya. Otak anak menurut Hasan (2013:159) mempunyai satu triliun sel otak dan bertriliun-triliun sambungan antar sel saraf otak. Kondisi ini mengharuskan orang tua atau keluarga terdekat untuk membantu mengaktifkan saraf-saraf tersebut. Apabila otak anak tidak distimulasi sejak dini, maka akan mengalami kepunahan sambungan saraf. Ibarat tanaman yang tidak disiram, ia akan layu kemudian mati.

Penelitian mengenai otak manusia menunjukkan bahwa perkembangan intelektual otak anak usia 4 tahun pertama sejak anak dilahirkan berkembang pesat menjadi $50 \%$. Pada usia 4-8 tahun bertambah $30 \%$. Pada usia 18 bertambah $20 \%$. Hasil penelitian mengenai otak ini menunjukkan bahwa simulasi otak yang dilakukan empat tahun pertama kehidupan seorang anak akan sangat bermanfaat bagi kehidupan sang anak di masa depan. IQ (Intelligence Quotient) anak ukuran rata-rata adalah 90-110. Apabila IQ anak berada di bawah range, maka ia tergolong anak yang berlQ rendah. Terdapat sebuah penelitian yang dilakukan oleh Hurt dkk, mereka menggali dua kelompok yang sama-sama dibesarkan dalam sebuah kemiskinan. Beberapa tahun ketika nak-anak 
menginjak usia remaja, para peneliti mengambil citra MRI (Magnetic Resonance Imaging) otak mereka untuk dicocokkan dengan kehangatan dan pola pengasuhan pada usia 4-8 tahun.

Hasil penelitian menunjukkan bahwa ada keterkaitan erat antara pengasuhan pada usia empat tahun dengan ukuran bagian otak yang terikat dengan ingatan. Sementara pada usia delapan bulan tidak menunjukkan keterkaitan apapun. Hemat kata, pentingnya lingkungan bagi perkembangan emosioanal AUD. Hasil penelitian lain juga menggambarkan bahwa anak yang lebih banyak mendapatkan perhatian dan pengasuhan di rumah cenderung memiliki IQ lebih tinggi, dibandingkan anak yang sedikit mendapat perhatian dan pengasuhan. Begitu halnya dengan anak yang mendapatkan stimulasi kognitif lebih banyak, meraka lebih terampil dalam kegiatan berbahasa. Adapun anakyang mendapatkan pengasuhan secara lebih hangat, mereka pun lebih mahir dalam kegiatan mengingat.

\section{Kesiapan Anak Mengenal Calistung Berdasarkan Aturan}

Masa balita adalah masa anak bermain dan bermain. Memaksakan anak melakukan sesuatu yang sebenarnya ia belum siap justru akan memberikan pengalaman yang tidak menyenangkan, bahkan akhirnya muncul penolakan. Direktur Jenderal Pendidikan Anak Usia Dini Nonformal dan Informal, Kemdikbud, Lydia Freyani Hawadi pernah mengingatkan bahwa jenjang PAUD seharusnya tidak membebani anak dengan kemampuan calistung. Siswa baru boleh diajar calistung di SD. Metode pendekatan di PAUD terfokus pada aspek motorik. Untuk itulah metode pebelajaran lebih menekankan pada pengembangan soft kill, yakni dapat dilakukan dengan cara bermain.

Anak yang terlalu difokuskan belajar calistung di usia dini dapat menimbulkan stres. Anak tidak dapat berkembang secara alami sebagaimana mestinya, serta tidak diberikan kesempatan untuk membangun fondasi yang kuat. Akibat tekanan yang dirasakan anak, mereka tidak dapat berkreativitas sesuai ide yang dimiliki. Sebaliknya, apabila anak terstimulasi dengan baik dan benar pada saat usia dini dan diberikan kesempatan untuk bermain, maka anak tersebut tidak akan menemui hambatan dalam belajar di kemudian hari dan anak tersebut distimulasi untuk menjadi lebih kreatif. 
Bentuk permainan yang terarah merupakan fondasi yang penting untuk menunjang kesempurnaan dalam kemampuan belajar di kemudian hari. Suatu misal, orang tua merasa bahwa anaknya tidak perlu distimulasi motorik halusnya. Dalam hal ini menstimulasi keterampilan tangan. Orangtua langsung mengajarkan anaknya untuk menulis. Akibatnya, anak berumur 6 tahun, tetapi anak tersebut tidak dapat menulis dengan baik atau tidak dapat menulis dalam angka waktu yang lama. Dengan alasan, tanganya cepat letih.

Contoh lain, anak tidak distimulasi motorik halusnya. Kemampuan merangkak pada anak memberikan stimulasi yang banyak terhadap anak, seperti menstimulasi konsentrasi mata, koordinasi dan kekuatan otot tubuh. Tetapi karena diburu-buru untuk berjalan cepat dengan cara dititah atau menggunakan alat bantu berjalan (walker), anak tersebut cenderung kehilangan kesempatan untuk distimulasi secara benar. Padahal anak yang terstimulasi dengan baik dan benar pada saat usia dini dan diberikan kesempatan untuk bermain, anak tersebut tidak akan menemui hambatan dalam belajar di kemudian hari dan justru anak menjadi lebih kreatif (Hawadi, Kompas, 2012).

Hal penting yang harus dilakukan orang tua/pengasuh yaitu membiarkan setiap fase perkembangan anak dilalui dan dikuasai secara alami. Anak tidak perlu dipaksa secara instant untuk melakukan hal-hal yang tidak cocok untuk usianya. Anak harus diberikan waktu untuk berkembang secara alami serta waktu bermain yang banyak dan terarah. Yang terpenting adalah anak diberikan fondasi yang kuat dan otak distimulasi secara maksimal agar anak siap menghadapi tantangan pada saat sekolah nanti. Terkait usia anak, telah dilakukan penelitian 1920-1930. Penelitian mengenai waktu yang tepat bagi si kecil untuk memulai belajar membaca. Hasil penelitian menunjukkan bahwa si kecil mulai belajar membaca jika sudah mencapai umur mental, yakni usia 5-5.5 tahun. Penemuan ini mengisyaratkan bahwa usia anak yang mencapai umur mental lebih mudah belajar membaca dibandingkan dengan usia anak yang belum mencapai umur mental (Hasan, 2013:310).

\section{Urutan Mengajarkan Calitung Pada Anak}

Calistung yang akan diajarkan kepada anak hendaknya sistematis dan terstruktur. Tahapan membaca mulai tingkat 
paling dasar hingga tingkat terkompleks. Begitu halnya dengan tahapan menulis dan berhitung. Berikut uraian setiap tahapan dalam calistung:

\section{Membaca}

Membaca merupakan keterampilan yang dituntut oleh banyak orang tua agar dikuasai anak sedini mungkin. Namun membaca ini sendiri memiliki tahapan yang harus dilalui anak seiring perkembangan usianya. Tahapan membaca pada anak usia dini, yaitu :

Tahap I: Membaca gambar

Secara teknis anak diberikan gambar, yang dalam satu halaman hanya memuat satu jenis gambar. misalnya jika di situ ada gambar apel, maka gambar tidak boleh dihias dengan jenis gambar lain. apabila berupa buku, maka buku tersebut hanya berisi gambar, belum tulisan.

Contoh: gambar apel

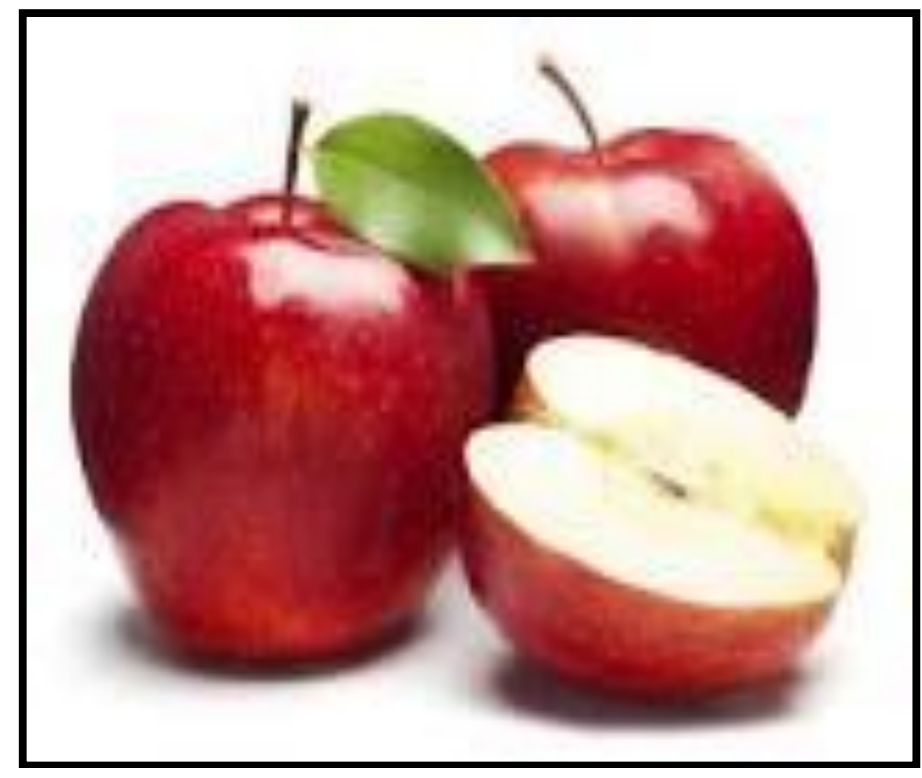

Tahap II: Membaca gambar + huruf

Keterampilan membaca anak tahap kedua ini dengan membaca huruf yang sesuai dengan huruf awal gambar. Contoh : 


\section{ZULFATUN ANISAH}

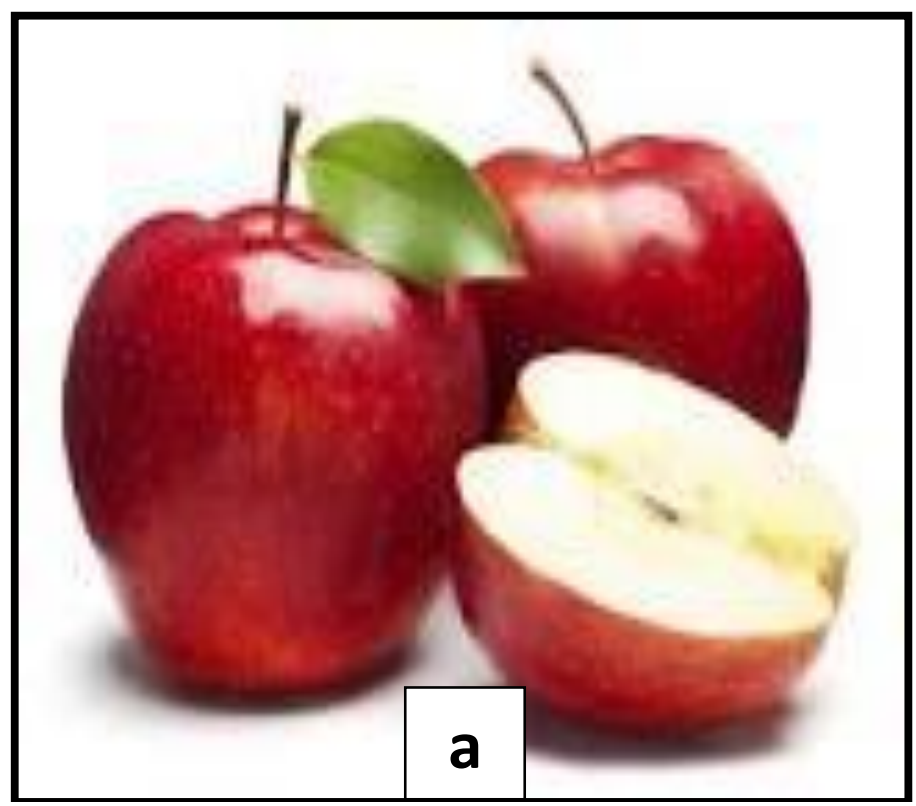

Tahap III: Membaca gambar+kata

Keterampilan membaca tahap selanjutnya adalah dengan memperlihatkan gambar dan tulisan makna gambar. Contoh :

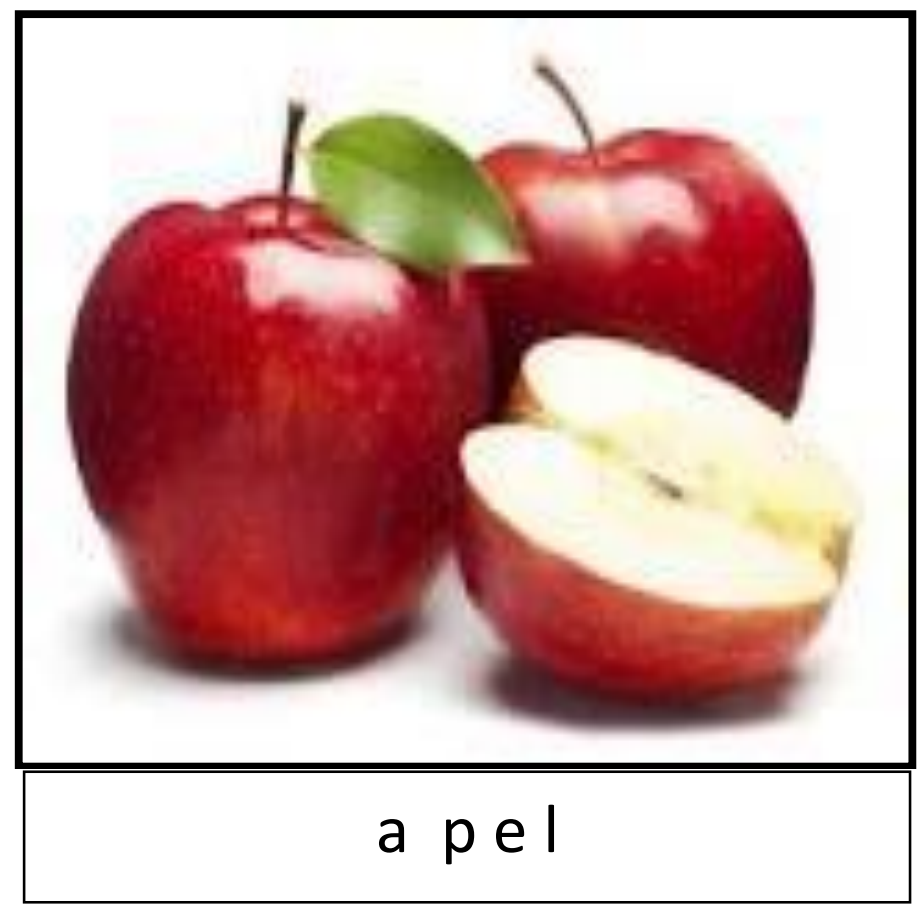




\section{Membaca kalimat}

Tahap membaca kalimat merupakan tahap paling matang dari keterampilan membaca ini. Pada tahap ini anak sudah menguasai banyak kosa kata dan dapat merangkainya menjadi kalimat. Anak dapat membaca buku, majalah maupun surat kabar.

\section{Menulis}

Menulis pra-alpabet adalah tulisan yang dibuat tidak berbunyi atau tidak dapat dibaca. Anak sekedar menulis berupa coretan atau gambar yang tidak memiliki makna bacaan. Coretan ini berupa simbol gambar yang menggambarkan imajinasi anak. Adapun tahapan prealphabetic ini meliputi :

1. Coretan Bebas, berupa coretan-coretan acak yang diciptakan dari garis hasil gerakan sederhana tangan. Contoh
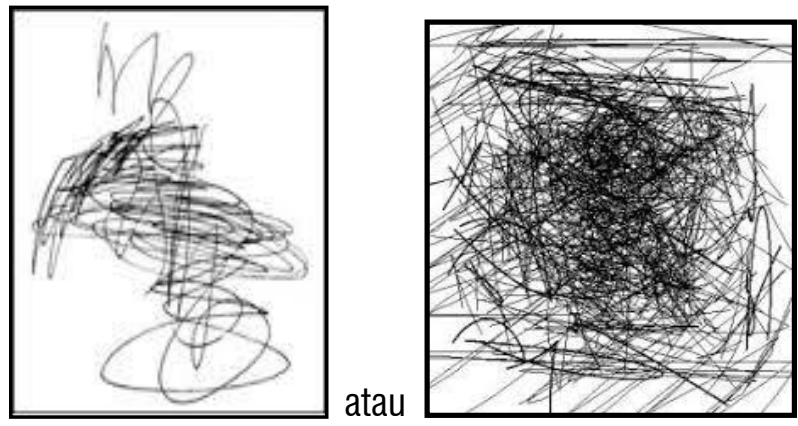

2. Coretan terkontrol, yaitu tulisan terarah dimunculkan dalam bentuk garis lurus ke atas atau mendatar yang diulang-ulang. Contoh

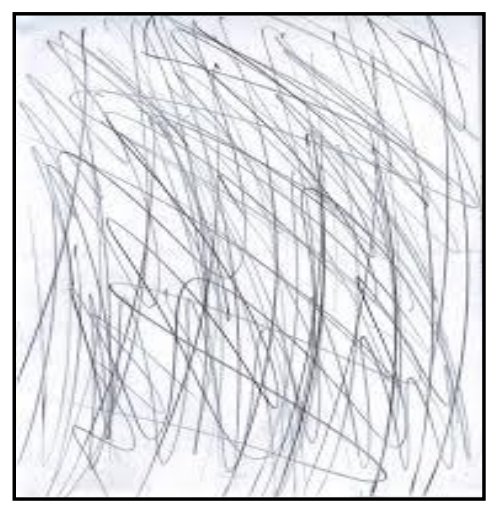


3. coretan bermakna. Anak mulai memberi label atau penjelasan mengenai coretan mereka dan melihat hubungan antara tanda dikertas dan ide, benda serta objek. Contoh

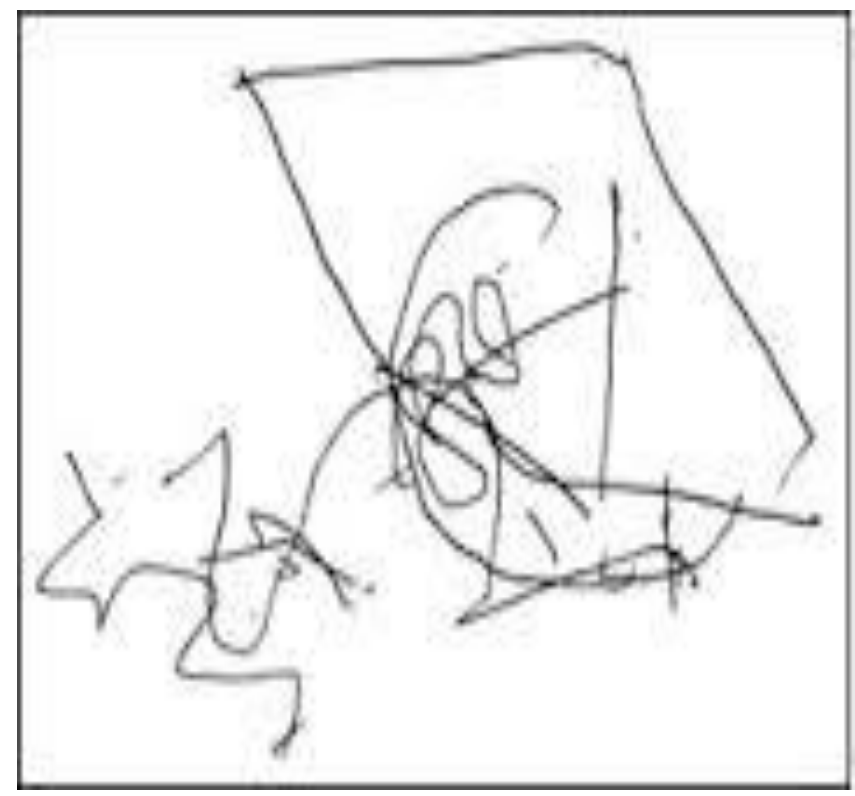

\section{Menulis Alphabet}

1. Kegiatan Awal Menulis Kata, anak mulai menulis rentetan huruf-huruf yang dapat dibaca, tetapi belum mengenal spasi. Contoh

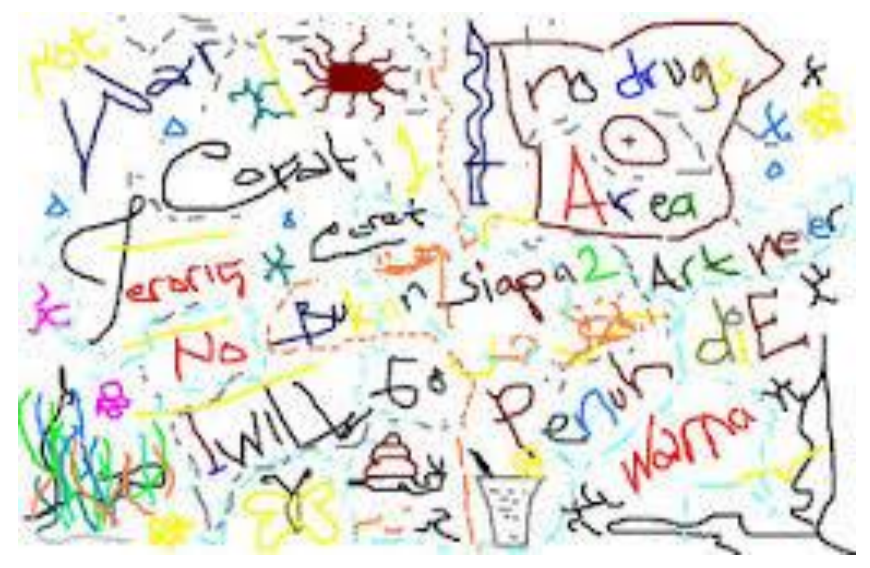

2. Menulis Rangkaian Kata, anak mulai peduli terhadap bunyi bacaan yang berhubungan dengan simbol walaupun tidak 
berhubungan, selalu menggunakan huruf kapital, dan tidak menggunakan spasi. Contoh:

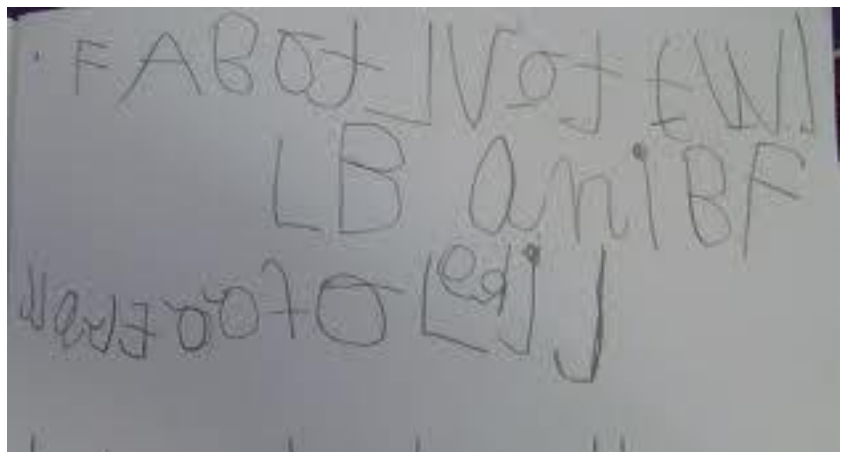

3. Menulis kalimat. Anak menggunakan huruf kapital dan huruf kecil secara bersamaan (campuran), anak mulai mengenal spasi antar kata, serta dapat menulis kalimat.

\section{Berhitung}

Berhitung merupakan salah satu kegiatan matematika dan menjadi dasar bagi kegiatan matematika selanjutnya. Berhitung juga erat kaitannya dengan aktivitas kehidupan sehari-hari yang akan dijalani anak. Karenanya berhitung ini perlu diajarkan sedini mungkin dengan metode yang tepat dan sesuai dengan karakteristik anak usia dini. Metode berhitung pada anak usia dini diajarkan dengan tahapan:

1. Pengalaman. Berhitung diajarkan dengan memberi kesempatan seluas-luasnya pada anak untuk melakukan aktivitasnya sendiri menggunakan benda konkret.

2. Simbol. Berhitung dapat dilakukan dengan menggunakan simbol, ketika tidak dimungkinkannya berhitung menggunakan benda konkret.

3. Tulisan. Huruf atau tulisan merupakan lambang bilangan yang sangat abstrak bagi anak-anak. Berhitung menggunakan tulisan hanya dapat diberikan pada anak yang telah memiliki pengalaman melakukan aktivitas sendiri menggunakan benda konkret dan simbol. 

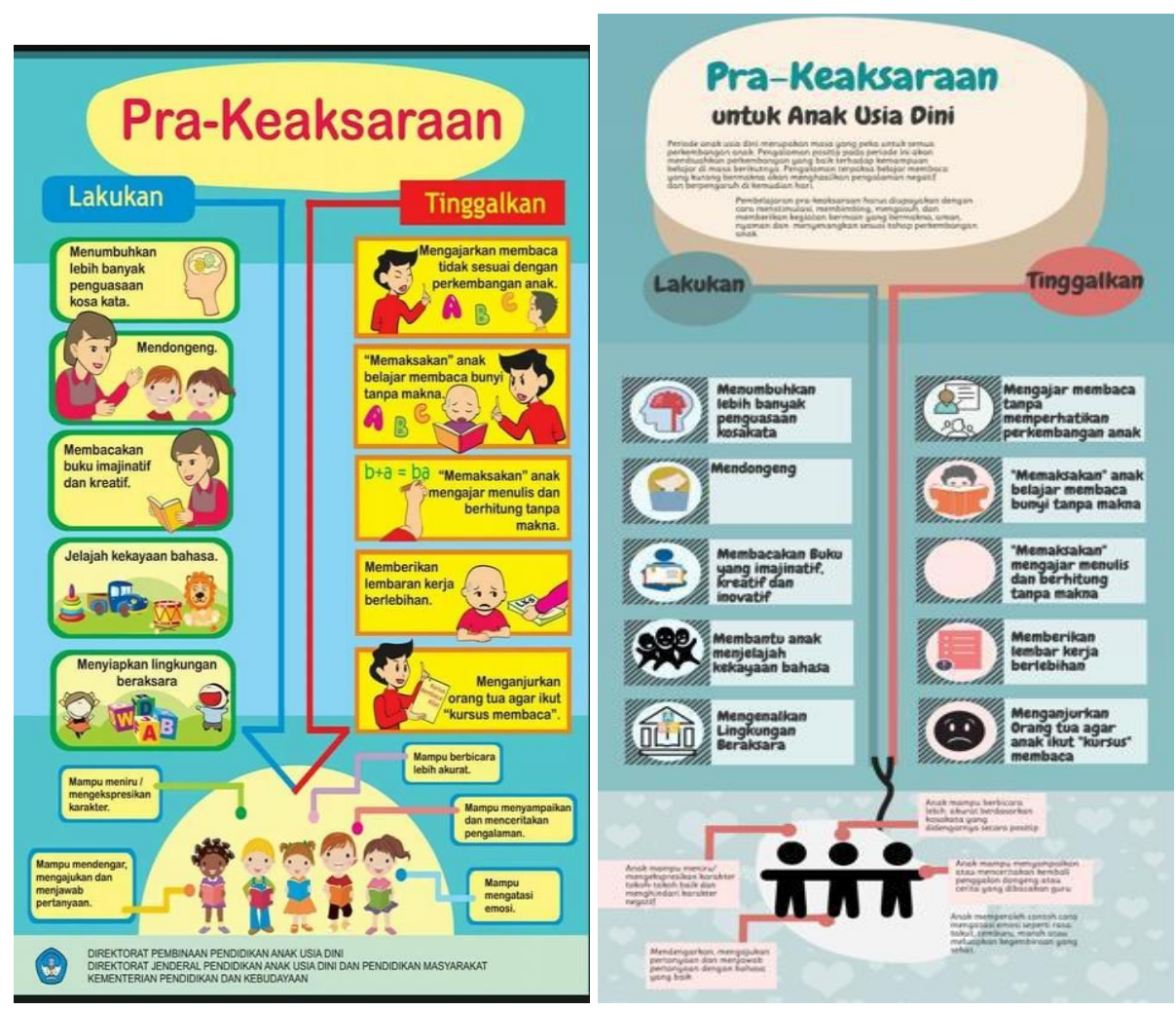

(dok. Kemendikbud)

\section{SIMPULAN}

Hal penting yang harus dilakukan orang tua/pengasuh yaitu membiarkan setiap fase perkembangan anak dilalui dan dikuasai secara alami. Anak tidak perlu dipaksa secara instant untuk melakukan hal-hal yang tidak cocok untuk usianya. Anak harus diberikan waktu untuk berkembang secara alami serta waktu bermain yang banyak dan terarah. Yang terpenting adalah anak diberikan fondasi yang kuat dan otak distimulasi secara maksimal agar anak siap menghadapi tantangan pada saat sekolah nanti. Terkait usia anak, telah dilakukan penelitian 1920-1930. Penelitian mengenai waktu yang tepat bagi si kecil untuk memulai belajar membaca. Hasil penelitian menunjukkan bahwa si kecil mulai belajar membaca jika sudah mencapai umur mental, yakni usia 5-5.5 tahun. Penemuan ini mengisyaratkan bahwa usia anak yang mencapai umur mental lebih mudah belajar membaca dibandingkan dengan usia anak yang belum mencapai umur mental. 
Kajian literatur ini akan lebih sempurna apabila pembaca atau peneliti melakukan penelitian lebih mendalam. Dengan harapan, memperoleh jawaban yang benar-benar komprehensif. Calistung yang diajarkan diberbagai tempat pendidikan anak usia dini dapat menjadi bahan pemerolehan data. Selanjutnya, akan didapatkan perbandingan hasil capaian berdasarkan tingkat calistung di setiap sekolah tingkat PAUD.

\section{REFERENSI}

Dardjowidjojo, Soenjono. 2012. PSIKOLINGUISTIK: Pengantar Pemahaman Bahasa Manusia. Jakarta: Yayasan Pustaka Obor Indonesia.

Geschwind, Norman. 1981. Specializations of the Human Brain. San Fransisco:W.H. freeman and Company.

Hasan, Maimunah. 2013. Pendidikan Anak Usia Dini. Jogjakarta: DIVA Press.

Hawadi. 2012. Perlukah Mengajarkan Calistung di Usia Dini?.Kompas.com - 13/06/2012, 13:59 WIB.

Santrock, John W. 2007. Educational Psychology: Terjemahan TriWibowo. Jakarta:Kencana.

Semiwan. 1997. Perspektif Pendidikan Anak Berbakat. Jakarta:Grasindo.

Steinberg, dkk. 2001. Psycholinguistics:Languange, Mind, and World. Cambride: Cambridge University Press.

Wahyuti. 2010. Online (Error! Hyperlink reference not valid., 7 Mei 2017, 11.07 WIB). 
ZULFATUN ANISAH

222 | AL HIKMAH: INDONESIAN JOURNAL OF EARLY CHILDHOOD ISLAMIC EDUCATION | VOL.1 (2), 2017 